\title{
Biotrophic Development of Sporisorium reilianum f. sp. zeae in Vegetative Shoot Apex of Maize
}

\author{
C. Martinez, C. Roux, and R. Dargent
}

Université Paul Sabatier, Laboratoire de Mycologie Végétale, Pôle de Biotechnologie Végétale, Chemin de Borde-Rouge, Auzeville, 31326 Castanet-Tolosan, BP 17, France.

Accepted for publication 16 November 1998.

\begin{abstract}
Martinez, C., Roux, C., and Dargent, R. 1999. Biotrophic development of Sporisorium reilianum f. sp. zeae in vegetative shoot apex of maize. Phytopathology 89:247-253.

Sporisorium reilianum f. sp. zeae is the causal agent of maize head smut, a disease present in several regions of France. A cytological study was carried out to describe a key step of the fungal etiology, in which the mycelium invades the vegetative shoot apex. Light and transmission elec-

tron microscopy observations show that the fungus is mostly intracellular and suggest that it passes through the host cell wall by lysis and mechanical pressure. The hyphae are surrounded by an amorphous vesicle-rich layer limited by a membrane related to the host plasmalemma. The encasement can be considered as an exchange zone between the plant and the fungus. The infected host cells appear normal; therefore, the fungus seems to act like a biotrophic endophyte.
\end{abstract}

Head smut of corn (Zea mays L.) is a disease caused by Sporisorium reilianum f. sp. zeae (Kühn) Langdon and Fullerton (Basidiomycota, Ustilaginaceae). The incidence of this soil fungus in the west of France was first noted in the beginning of the 1980s. Chemical treatment of soil or seeds and the use of tolerant corn varieties have proven effective in infected fields. However, these approaches have only delayed the spread of the fungus, and head smut now occurs in several regions of France. Even though several reports deal with the resistance mechanisms of corn or sorghum to this disease $(2,5,8,18,26)$, an understanding of the biology of the fungus is a prerequisite for the development of new control strategies.

The histopathology of $S$. reilianum $\mathrm{f}$. sp. zeae has been far less extensively described than that of other smut fungi $(9,13,16,22)$. The main characteristics of the life cycle of $S$. reilianum $\mathrm{f}$. sp. zeae can be gleaned from a compilation of several partial works $(11,19)$ and extrapolation of data from $S$. reilianum $\mathrm{f}$. sp. reilianum on sorghum $(10,28)$ and from other smuts. $S$. reilianum f. sp. zeae is a dimorphic fungus with a saprobiotic yeast phase and a parasitic mycelial phase. Plants are only infected by soilborne teliospores during seedling emergence. The teliospores germinate into a basidium, forming yeast-like basidiospores. Mating of compatible cells leads to a parasitic mycelium that infects the maize roots and grows up to the vegetative apex. After sporogenesis, the ear is entirely or partially replaced by a black sorus. Matyac (14), using light microscopy and scanning electron microscopy, described the fungal distribution of $S$. reilianum $\mathrm{f}$. sp. zeae in young sori of maize. However, little is known about earlier events of the interaction. It can be noted that this fungus is very discrete until sporogenesis; the symptoms are rarely discernable on the vegetative parts of the plant. The growth of the mycelium up to the apical meristem is a key step in the development of the fungus because sporogenesis depends on its presence in the shoot apex and, therefore, in the floral meristem. This is also an important phase for the crop because the level of colonization of the shoot apex by the fungus can

Corresponding author: C. Roux; E-mail address: roux@ cict.fr

Publication no. P-1999-0121-02R

(C) 1999 The American Phytopathological Society cause partial or total destruction of the ear after sporulation, resulting in drastic yield losses. We focused our attention on the events prior to sporogenesis. We used light and transmission electron microscopy (TEM) to describe the fungus in the vegetative shoot apex of maize, before floral induction.

This work is part of a general study on fungal biology and cytological relationships between $S$. reilianum $\mathrm{f}$. $\mathrm{sp}$. zeae and maize.

\section{MATERIALS AND METHODS}

Biological material. The teliospores of S. reilianum f. sp. zeae were collected in a maize field at Saint Sauveur (Haute Garonne, France). A susceptible corn (Zea mays) cultivar DK 300 (R.A.G.T. S.A., Rodez, France) was used in our assays. Maize seeds were sterilized with $2 \%$ (wt/vol) chloramine T (Sigma Aldrich, Saint Quentin, Flavier, France) in $\mathrm{H}_{2} \mathrm{O}$ for $15 \mathrm{~min}$ and rinsed in sterile distilled water. Sterility efficiency was verified by germination on potato dextrose agar (PDA) (Difco Laboratories, Detroit). Three days later, the seeds free of microbial contamination were transferred to sterilized $\left(1 \mathrm{~h}\right.$ at $\left.120^{\circ} \mathrm{C}\right)$ compost. Inoculation was performed at the same time by adding $0.5 \mathrm{ml}$ of teliospores $\left(10^{6}\right.$ teliospores per $\left.\mathrm{ml}\right)$ to the seeds. Teliospores were prepared by rinsing twice for $10 \mathrm{~min}$ in sterile distilled water, followed by incubation for $12 \mathrm{~min}$ in $2 \%$ (wt/vol) chloramine T (Sigma Aldrich) and washing in sterile distilled water.

Plants were grown in a greenhouse at $24 \pm 5^{\circ} \mathrm{C}$, and shoot apices were dissected after 5 weeks of development.

Light microscopy. Infected vegetative apices (5 weeks of maize growth in our culture conditions, leaf number 5) were cut into two pieces and cleared with $10 \% \mathrm{KOH}$ for $1 \mathrm{~h}$. The sections were stained with cotton blue in lactophenol and rinsed in lactophenol for $10 \mathrm{~min}$. The sections were mounted in distilled water and examined with an inverted Leica DMIRBE Leitz microscope (Leica Mikroskope und Systeme GmbH, Wetzlar, Germany). Figure 1B was acquired with a color cool view device camera (Photonic Science, Robertsbridge, East Sussex, United Kingdom) and transferred to a personal computer.

Tissue processing for TEM. Meristems were fixed in $3 \%$ glutaraldehyde in $0.1 \mathrm{M}$ sodium cacodylate buffer $(\mathrm{pH} \mathrm{7.2)}$ for $2 \mathrm{~h}$ at room temperature. Material was postfixed in $1 \%$ osmium tetroxide in the 
same buffer before being dehydrated in a graded ethanol series. Preparations were embedded in Spurr's epoxy resin (25) or, after additional dehydration in propylene oxide, embedding was performed in Epon 812 (Euromedex, Souffelweyersheim, France). Ultrathin sections were cut on a Reichert OMU3 microtome (Leica, Rueil-Malmaison, France) and collected on gold grids. For examination, sections were stained for $10 \mathrm{~min}$ with uranyl acetate and $5 \mathrm{~min}$ with lead citrate at room temperature. Sections were examined on a Philips 301 electron microscope at $80 \mathrm{kV}$ (Philips, Eindhoven, the Netherlands).
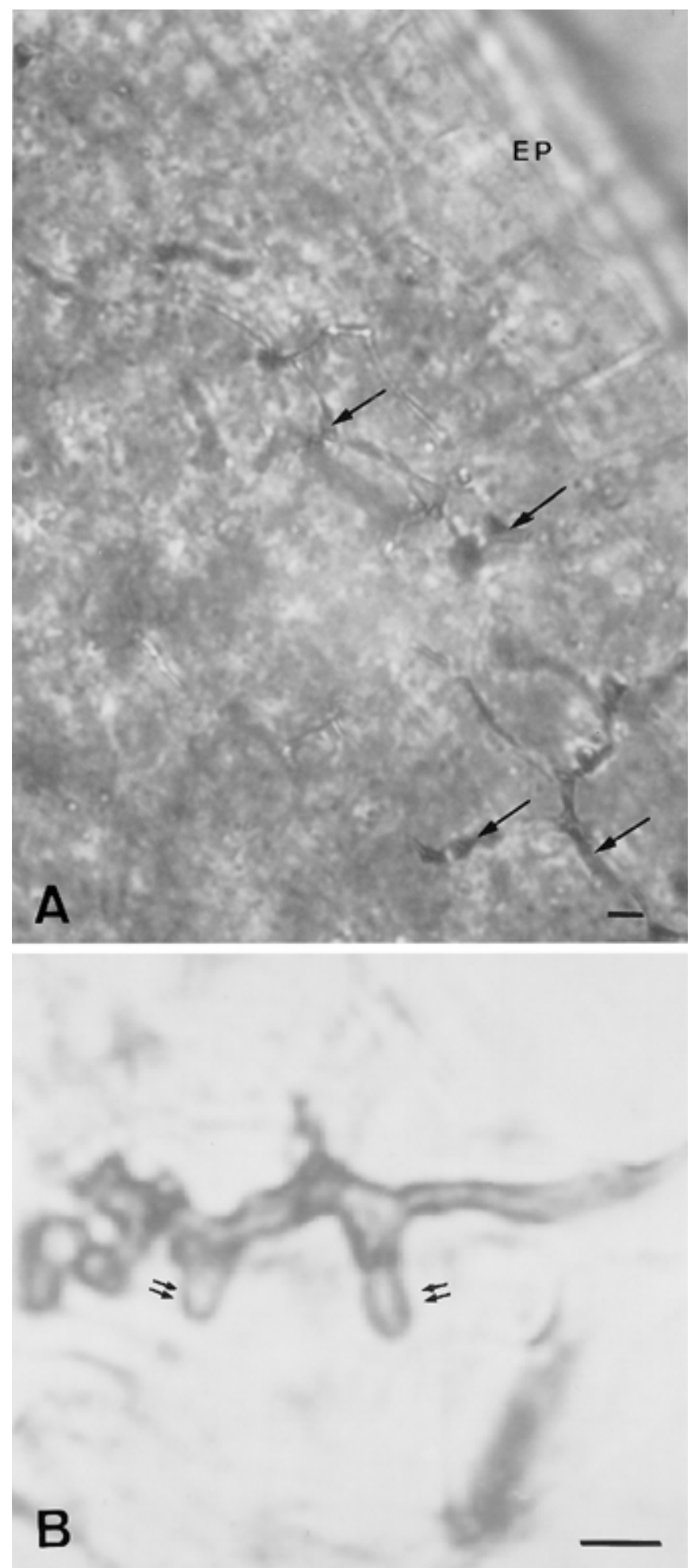

Fig. 1. Light micrographs of mycelium of Sporisorium reilianum $\mathrm{f}$. $\mathrm{sp}$. zeae in a vegetative shoot apex of maize stained with cotton blue. A, Hypha (arrows) under the epiderm (EP). $\times 400$; bar $=10 \mu \mathrm{m}$. B, Micrograph of hypha with finger-like projections (double arrows). $\times 1,000$; bar $=10 \mu \mathrm{m}$.
Cytochemical techniques. Cytochemical detection of polysaccharides was performed by PATAg labeling (periodic acid, thiocarbohydrazide, silver proteinate) according to Dargent and TouzéSoulet (6). The specificity of the reaction was assessed on control sections without the thiocarbohydrazide $(\mathrm{TCH})$ treatment.

Lectin from Triticum vulgaris (wheat germ agglutinin) labeled with $10 \mathrm{~nm}$ of colloidal gold (WGA-Au ${ }^{10}$ complex) was purchased from Sigma Aldrich. The grids were first floated with the sections on the undersurface for $5 \mathrm{~min}$ on a large drop of $0.05 \mathrm{M}$ phosphate-buffered saline (PBS), $\mathrm{pH}$ 7.0. They were subsequently incubated on a drop of colloidal gold complex for periods ranging from 1 to $2 \mathrm{~h}$. After incubation, the sections were thoroughly washed with PBS and distilled water and then contrasted with uranyl acetate and lead citrate before examination.

The specificity of the cytochemical reactions was assessed in the following experiments: (i) incubation of WGA-gold with 1 to $10 \mathrm{mg}$ of $\mathrm{N}, \mathrm{N}^{\prime}, \mathrm{N}^{\prime \prime}$-triacetylchitotriose (Sigma Aldrich) per ml before labeling the sections, (ii) incubation of sections with WGA before treatment with WGA-gold complex, and (iii) incubation with the gold suspension alone.

\section{RESULTS}

Light microscopy observations of the fungus in the vegetative part of maize are summarized in Figure 1. S. reilianum f. sp. zeae did not show any visible symptoms in the meristem tissues of apical buds. After staining with cotton blue, the mycelium was difficult to observe (Fig. 1A). It appeared as short, straight, septate filaments (Fig. 1B) with digitations (finger-like projections) growing through the cell compartments.

Electron microscope examination of ultrathin sections made through the vegetative apex showed that the fungus was present in the elongation zone (Fig. 2A) and the apical zone (Fig. 2B) of the meristem. We observed that the hyphae were mostly intracellular (Fig. 2B), but they sometimes could occur in the intercellular spaces (Fig. 2A). The intracellular hyphae were always surrounded by the host cell plasmalemma, which was never perforated. The mycelium, with a diameter of 2 to $4 \mu \mathrm{m}$, exhibited an electron transparent cell wall after double-staining with uranyl acetate-lead citrate (Fig. 2A), highly contrasted with PATAg labeling (Fig. 2B). The cell wall, $0.2 \mu \mathrm{m}$ thick, appeared to have only one layer, which differed from a two-layered cell wall observed on pseudomycelium in vitro (data not shown) and from other dimorphic fungi such as Taphrina spp. (21). Observation of sections after treatment with WGA-gold complex revealed that gold particles were distributed in the fungus cell wall and no significant background was noted in the host and fungal cytoplasm (Figs. 2A and 3D). WGA-labeling controls were negative. The WGA labeling revealed differentiation of the fungal cell wall from the encasement (Fig. 3C and D). It should be noted that chitin was present in the fungus cell wall of both the intercellular and intracellular hyphae (Figs. 2A and 3D).

The hyphae showed atypical septa, forming unpored discs between cells. They were convex towards the apex (Fig. 3A, arrowhead) and presented an inner zone that was unstained after PATAg treatment (Fig. 3B). The septa were formed by centripetal invagination of the internal layer of the cell wall (Fig. 3A, arrow). Distal cells appeared highly vacuolated and without organelles (Fig. 3A).

Apical cells of the hyphae were characterized by a ribosome-rich cytoplasm that contained the different endomembrane systems and organelles: endoplasmic reticulum, nucleus, and mitochondria (Fig. 3A). Some lipid globules, small vacuoles, microvesicles, and glycogen areas were also visible in the fungus (Fig. 4C and D).

The presence of the fungus did not seem to provoke significant ultrastructural alterations inside the host cells; mitosis remained active and chromatine was visible (Fig. 2A), and the different endomembrane systems were conserved (Figs. $2 \mathrm{~A}$ and $\mathrm{B}$ and $4 \mathrm{~A}$ ). However, when the mycelium touched the host cell wall (Fig. 4B), a lytic process followed (Fig. 4C). At the point of contact, PATAg 
labeling showed small, isolated, electron-dense precipitates, revealing disorganization of the host cell wall after it had lost its fibrillar structure (Fig. 4C). Finally, the mycelium passed through the cell wall, apparently without constriction (Fig. 4D). Around the penetration site, the host cell wall material exhibited asymmetry; the penetrating hypha seemed to push away the hydrolyzed cell wall material and the host membrane (Fig. 4D, arrowhead). It was, therefore, possible to determine the direction in which the hypha was growing.

Finally, the presence of a sheath of variable thickness around the hyphae should be mentioned (Fig. 5A, B, and C). It was divided into two parts (Fig. 5B): an electron-dense layer after label-
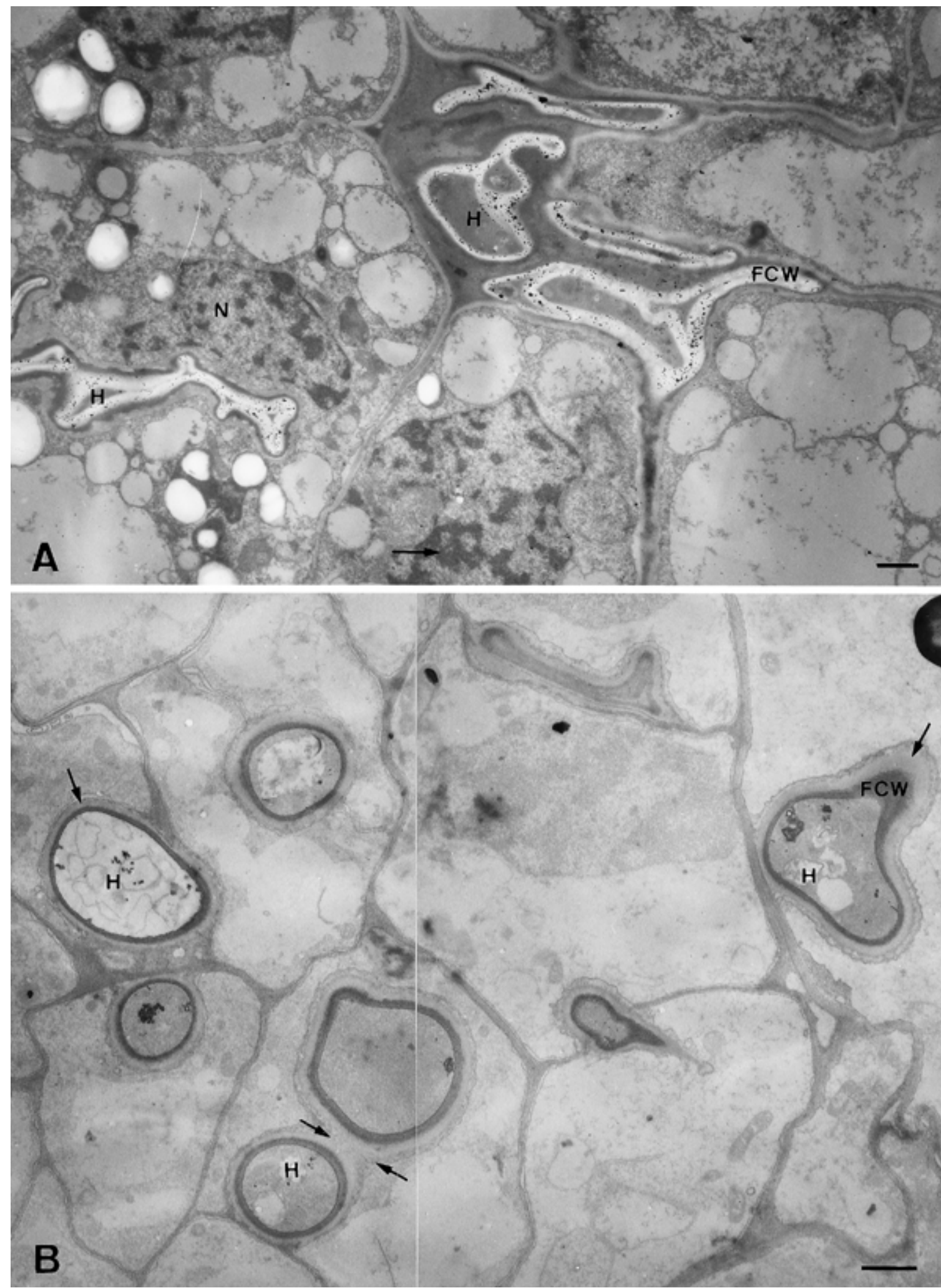

Fig. 2. Transmission electron micrograph of a vegetative shoot apex infected by Sporisorium reilianum f. sp. zeae. A, Transverse section of intercellular and intracellular hyphae $(\mathrm{H})$ in the elongation zone of the meristem. The presence of the fungus does not induce ultrastructural alterations in the host cells $(\mathrm{N}=$ nucleus; arrow indicates chromatine). After WGA-gold complex treatment, the fungal cell wall (FCW) is strongly labeled. $\times 6,800$; bar $=1 \mu \mathrm{m}$. B, Transverse section of $\mathrm{H}$ in the apical zone of the meristem, stained with PATAg. The FCW, electron dense, is surrounded by a sheath $(\operatorname{arrow}) . \times 9,000 ;$ bar $=1 \mu \mathrm{m}$. 
ing with uranyl acetate-lead citrate that was joined to the fungal cell wall and appeared amorphous; and an external, unlabeled layer containing vesicular structures. The sheath was surrounded by an invaginated membrane connected to the host cell plasmalemma (Figs. 3A and 4B). This membrane was also connected to vesicular structures containing PATAg-positive fibrillar material (Fig. 5C, arrowhead). Moreover, an accumulation of electron-dense deposits (Fig. 5B, arrowhead) was observed near the membrane. This organization (sheath and membrane) was observed in all the intracellular fungal structures present in the vegetative meristematic cells, and it sometimes surrounded several fungal cells (Figs. 2B and 5A).

\section{DISCUSSION}

Our results on the cytolocalization of $S$. reilianum $\mathrm{f}$. sp. zeae in the vegetative shoot apex demonstrate that the mycelium is mostly intracellular, even though intercellular hyphae are present in the youngest zone of the meristem. The intracellular hyphae pass through the host cell wall by a breaching mechanism that does not appear to constrict the mycelium. Asymmetry of the host cell wall deposits around the penetration site can be seen. We agree with Luttrel (13), who noted for other smuts that this asymmetry implies a mechanical effect of the hyphae perforating the host cell wall. However, polysaccharide staining by the PATAg technique reveals a loss of the fibrillar structure of the host cell wall in contact with the hypha, and the lysed host cell wall material diffuses between the fungus and the host plasmalemma. This strongly suggests that a hydrolytic mechanism occurs during the cell wall penetration.

The intracellular hyphae observed on ultrathin sections are formed by long cells separated by septa. Occasionally, these hyphae are branched. Some fungal cells are organelle-rich and are considered apical cells. Distal cells are vacuolated and do not possess an endomembrane system. Like Ustilago maydis (22), septation mostly occurs between active apical cells and vacuolated distal cells. The septa between the cells are formed centripetally from the inner layer of the fungal cell wall. Based on the numerous observations performed, it seems that this Sporisorium sp. has atypical septa that do not present any pores. This agrees with reports on smuts belonging to the order Ustilaginales (1), in which pores were only described in basidial septa (17). Moreover, Bauer et al. (1) have shown that the electron transparent middle layer of the septum in the family Ustilaginaceae is interrupted. In spite of several attempts, we did not see this organization on our serial sections. Lastly, the structure of the septum and the degeneration of the distal cells resemble the morphology of pseudomycelium obtained in vitro (C. Martinez, unpublished data).

Around the intracellular hyphae, we observed an amorphous layer that was usually thick and was divided into an inner, electron-dense zone and an external, clear zone containing vesicles. The layer is surrounded by an invaginated membrane originating from the host plasmalemma. This encapsulation could be compared with a haustorial structure described in plant-fungal parasite interactions $(4,7)$, in which an extrahaustorial matrix is surrounded with an extrahaustorial membrane. However, there are no haustoria sensu stricto in $S$. reilianum f. sp. zeae; encapsulation is visible around all the intracellular hyphae. We did not observe the typical differentiated structures that arise from vegetative mycelium as described in other phytopathogenic fungi. The terminology of these structures has been discussed by Luttrel (13) and Snetselaar and Mims (23), in which the terms "extrahaustorial matrix" and "the sheath" were named "interfacial matrix" and "encasement," re-

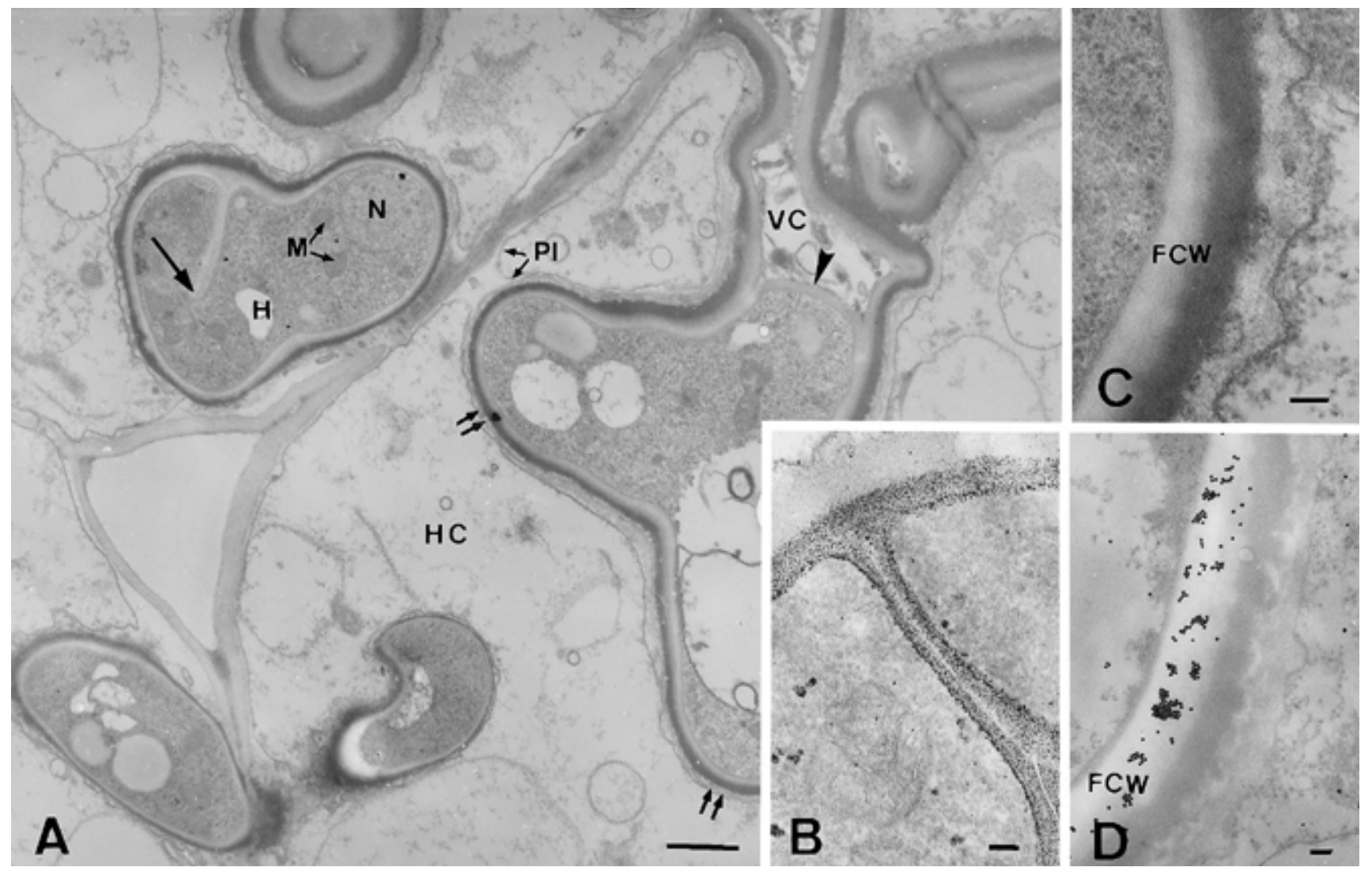

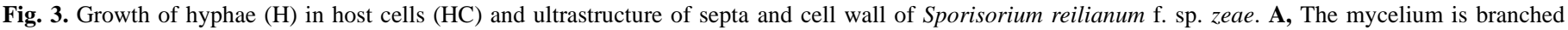

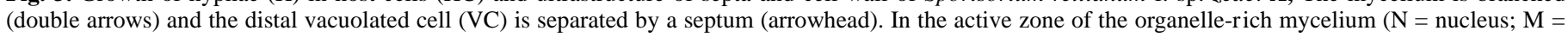

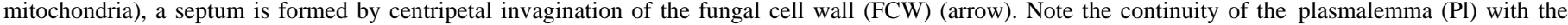

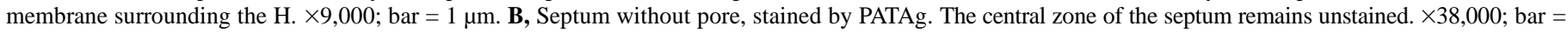

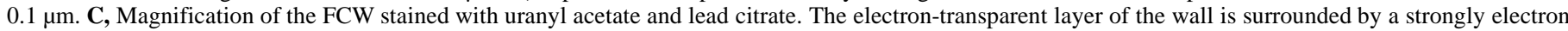
dense layer. $\times 50,000$; bar $=0.1 \mu \mathrm{m}$. D, Labeling by WGA-gold complex. The FCW is intensely labeled. $\times 30,000$; bar $=0.1 \mu \mathrm{m}$. 
spectively. This interaction zone sometimes surrounds several sections of hyphae of $S$. reilianum $\mathrm{f}$. sp. zeae. We cannot assert that the different sections result from branching of the hyphae or from coiling of the intracellular mycelium as described in $U$. nuda (13).

Bauer et al. (1) proposed that the encasement results only from "primary interactive vesicles" formed by the fungus. Although such fungal vesicles are present in $S$. reilianum $\mathrm{f}$. sp. zeae, the host cell could participate too, as indicated by the presence on the external membrane of vesicles containing polysaccharide material. The pathogen and the host seem to participate in building the encasement. The absence of this interface on intercellular hyphae supports the view that this structure is an exchange zone as described for endomycorrhizal fungi (3). Moreover, the presence of the encasement around the whole intracellular hypha suggests that the
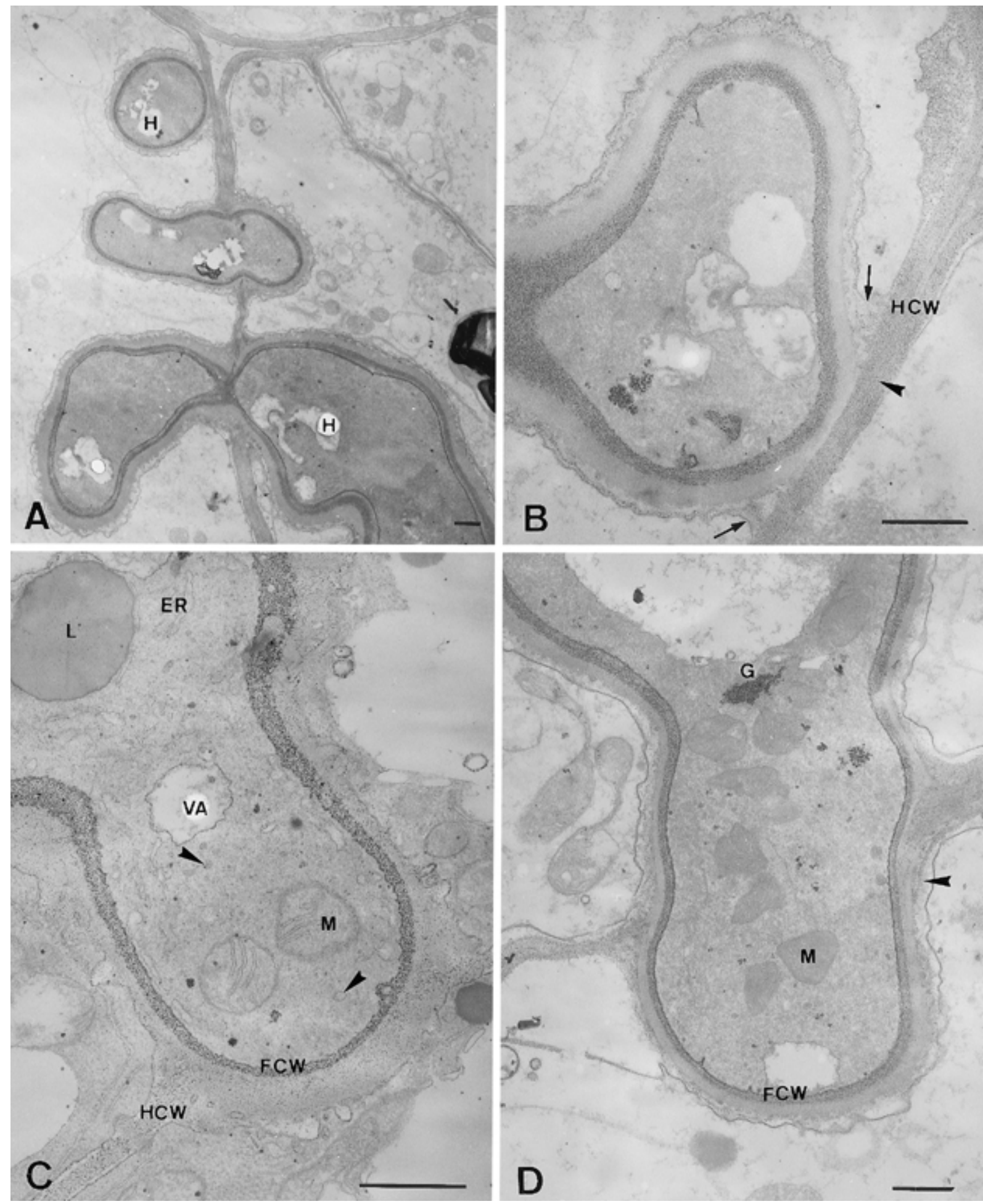

Fig. 4. Visualization of the interaction between intracellular hyphae and host cell wall (HCW) after PATAg staining. A, General view, in which host cells are invaded by intracellular hyphae $(\mathrm{H})$. The host cells do not show significant ultrastructural alterations. $\times 9,000$; bar $=0.5 \mu \mathrm{m}$. B, Intracellular mycelium in contact with the HCW. The fibrillar structure of the wall is visible (arrowhead). The membrane surrounding the hyphae is connected to the host plasmalemma (arrow). $\times 30,000$; bar $=0.5 \mu \mathrm{m}$. C, Disorganization of the HCW in contact with the fungal cell wall (FCW). The fungal cell is active as indicated by the presence of mitochondria (M) with cristae, endoplasmic reticulum cisternae (ER), and lipid globules (L). Vacuoles (VA) and microvesicles (arrowhead) are present in the fungus. $\times 38,000$; $\mathrm{bar}=0.5 \mu \mathrm{m}$. D, The $\mathrm{H}$ passes through the $\mathrm{HCW}$, pushing away the host cell membrane. Hydrolyzed HCW material (arrowhead) diffuses around the FCW. Many mitochondria (M) and glycogen areas (G) are present. $\times 22,000$; bar $=0.5 \mu \mathrm{m}$. 
entire fungus would have an exchange activity with the host. This, linked to the normal appearance of infected vegetative meristematic cells, indicates that the fungus acts like a biotrophic endophyte. As mentioned by Luttrel (13), there is a high degree of compat- ibility reached by the smut fungi and their hosts. This is particularly true for $S$. reilianum f. sp. zeae, which causes minimal symptoms on leaf and stem (reversible chlorotic spots and occasional anthocyan accumulation on stems), even though the fungus is sys-
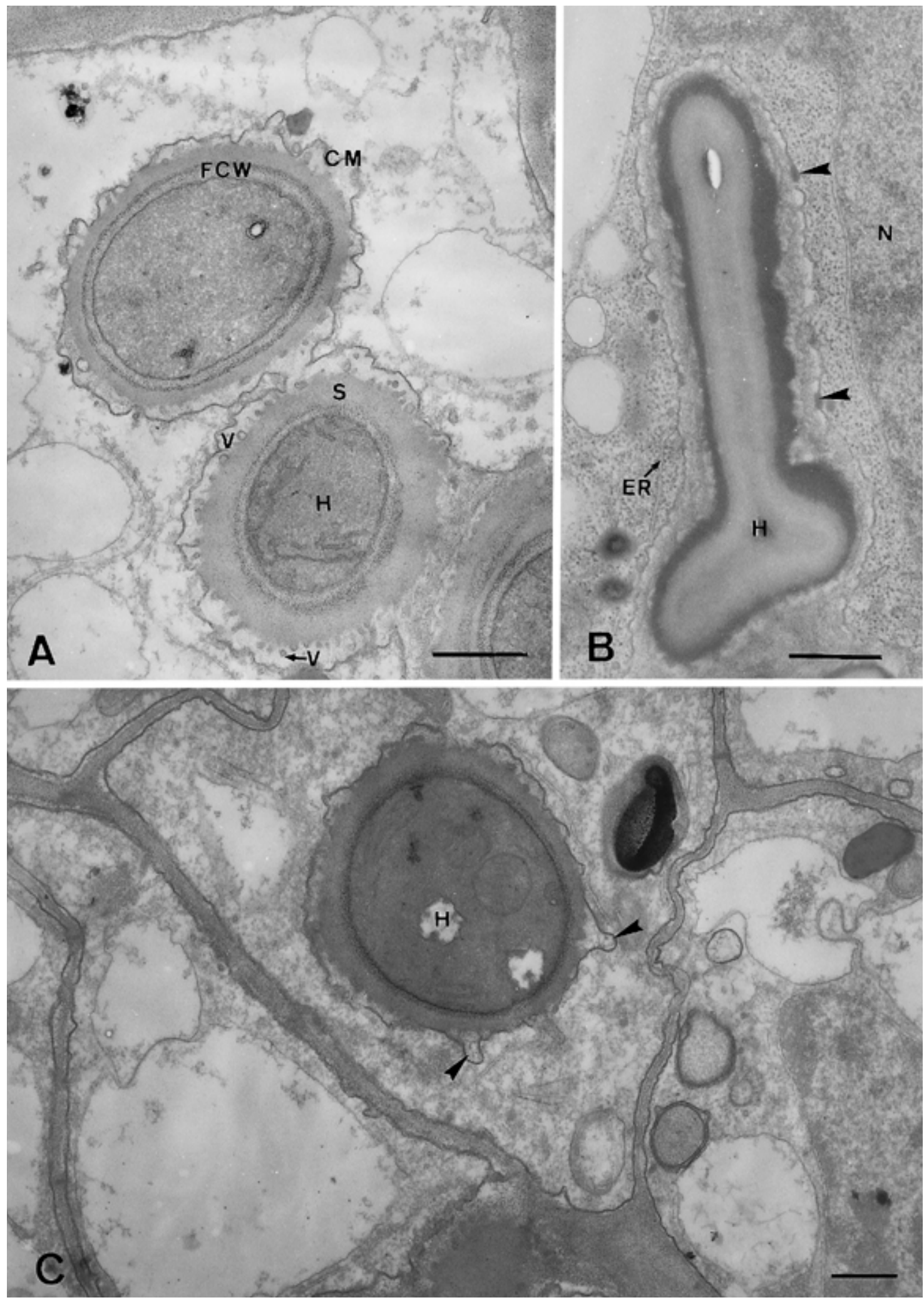

Fig. 5. Interfacial structures. A, Transverse section of intracellular mycelium after PATAg labeling. The fungal cell wall (FCW) of the hypha (H) is surrounded by a large sheath $(\mathrm{S})$, wrapped in a convoluted membrane $(\mathrm{CM})$. Vesicles $(\mathrm{V})$ are present in the external layer of the sheath. $\times 30,000$; bar $=$ $0.5 \mu \mathrm{m}$. B, Transverse section of intracellular mycelium after uranyl acetate and lead citrate labeling. Electron-dense deposits are visible (arrowhead) on the membrane surrounding the hypha $(\mathrm{H})$. The endomembranes of the host cell organelles, nucleus $(\mathrm{N})$, and reticulum $(\mathrm{ER})$ are preserved. $\times 30,000$; bar $=$ $0.5 \mu \mathrm{m}$. C, Transverse section of intracellular mycelium $(\mathrm{H})$ after PATAg labeling. Note the presence of vesicular structures containing fibrillar material (arrowhead). $\times 22,000 ;$ bar $=0.5 \mu \mathrm{m}$. 
temic (19). Later, sporogenesis of $S$. reilianum $\mathrm{f}$. sp. zeae (14) leads to the decline of the floral host tissue. The change of trophic behavior of the fungus is induced by the floral transition of maize.

Our observations contribute to a more complete description of the genus Sporisorium. Several authors $(9,13,16,23)$ have also observed, by TEM, an encasement around intracellular hyphae in other smuts. This was recently proposed to be a characteristic of the subclass Ustilaginomycetidae (1), but with some variations among the genera. At this level of the study, it is interesting to point out that there are few or even no ultrastructural differences between the mycelium of the graminicolous Ustilago and Sporisorium spp. $(9,13,16,23)$. No variations were found in spore ontogeny or teliospore wall structure (16). The distinction between the genera is based on sorus ontogeny $(12,15)$ and especially on the presence of nonsporogenous hyphae in Sporisorium spp., yielding a sorus covered by a peridium. However, the use of this morphological characteristic to delimit the genus Sporisorium is controversial. For example, the denomination Sporisorium provinciale, instead of Sorosporium provinciale, has been discussed (24), whereas the presence of a peridium occurs in some Ustilago spp. such as $U$. maydis (27). Additional ultrastructural investigations and molecular phylogenetic analyses (20) would be helpful to resolve the delimitation of the genus Sporisorium.

Our interest in $S$. reilianum f. sp. zeae centers on describing its biology. This should enable more efficient means of control to be developed. The barely visible symptoms caused by this pathogen on the vegetative part of maize emphasizes the value of early detection by molecular tools. Moreover, the biotrophic behavior of this fungus on the vegetative apex of maize underlines the likely effectiveness of a systemic treatment based on inhibition of mycelial growth, sporogenesis, or both until floral induction occurs.

\section{ACKNOWLEDGMENTS}

We thank A. Moisand for use of the electron microscope at the "Centre de Pharmacologie et Toxicologie Fondamentales" in Toulouse, France.

\section{LITERATURE CITED}

1. Bauer, R., Oberwinkler, F., and Vánky, K. 1997. Ultrastructural markers and systematics in smut fungi and allied taxa. Can. J. Bot. 75:1273-1314.

2. Bernardo, R., Bourrier, M., and Olivier, J. L. 1992. Generation means analysis of resistance to head smut in maize. Agronomie 12:303-306.

3. Bonfante, P., and Perotto, S. 1995. Strategies of arbuscular mycorrhizal fungi when infecting host plants. New Phytol. 130:3-21.

4. Bracker, C. E. 1968. Ultrastructure of the haustorial apparatus of Erysiphe graminis and its relationships to the epidermal cell of barley. Phytopathology 58:12-30.

5. Craig, J., and Frederiksen, R. A. 1992. Comparison of sorghum seedling reactions to Sporisorium reilianum in relation to sorghum head smut resistance classes. Plant Dis. 76:314-318.

6. Dargent, R., and Touzé-Soulet, J. M. 1976. Sur l'ultrastructure des hy- phes d'Hypomyces chlorinus Tul. cultivé en présence ou en absence de biotine. Protoplasma 89:49-71.

7. Ehrlich, M. A., and Ehrlich, H. G. 1971. Fine structure of the host-parasite interfaces in mycoparasitism. Annu. Rev. Phytopathol. 9:155-184.

8. Frederiksen, R. A. 1977. Head smuts of corn and sorghum. Pages 89-105 in: Proc. Annu. Corn Sorghum Res. Conf., 32nd. H. A. Loden and D. Wilkinson, eds. American Seed Trade Association, Washington, DC.

9. Fullerton, R. A. 1970. An electron microscopy of the intracellular hyphae of some smut fungi (Ustilaginales). Aust. J. Bot. 15:285-292.

10. Halisky, P. M., and Petersen, L. J. 1962. Systemic development and persistence of Sphacelotheca reiliana in Sudan grass. Phytopathology 52:541-544.

11. Hanna, W. F. 1929. Studies in the physiology and cytology of Ustilago zeae and Sorosporium reilianum. Phytopathology 19:415-443.

12. Langdon, R. F. N., and Fullerton, R. A. 1975. Sorus ontogeny and sporogenesis in some smut fungi. Aust. J. Bot. 23:913-930.

13. Luttrel, E. L. 1987. Relations of hyphae to host cells in smut galls caused by species of Tilletia, Tolyposporium and Ustilago. Can. J. Bot. 65:2581-2591.

14. Matyac, C. A. 1985. Histological development of Sphacelotheca reiliana on Zea mays. Phytopathology 75:924-929.

15. Mims, C. W., and Snetselaar, K. M. 1991. Teliospore maturation in the smut fungus Sporisorium sorghi: An ultrastructural study using freeze substitution fixation. Bot. Gaz. 152:1-7.

16. Mims, C. W., Snetselaar, K. M., and Richardson, E. A. 1992. Ultrastructure of the leaf strip smut fungus Ustilago striiformis: Host-pathogen relationship and teliospore development. Int. J. Plant Sci. 153:289-300.

17. O'Donnel, K. L., and McLaughlin, D. J. 1984. Ultrastructure of meiosis in Ustilago maydis. Mycologia 73:468-485.

18. Oh, B. J., Frederiksen, R. A., and Magill, C. W. 1994. Identification of molecular markers linked to head smut resistance gene (Shs) in Sorghum by RFLP and RAPD analyses. Phytopathology 84:830-833.

19. Potter, A. A. 1914. Head smut of sorghum and maize. J. Agric. Res. 2:339-380.

20. Roux, C., Almaraz, T., and Durrieu, G. 1998. Phylogeny of some smuts fungi based on ITS sequences analysis. (In French, with English abstract.) C. R. Acad. Sci. Ser. III Sci. Vie 321:603-609.

21. Schneider, A., and Dargent, R. 1972. Ultrastructure de la paroi et des septa du mycelium parasite de Taphrina deformans. (In French.) C. R. Acad. Sci. Ser. D 275:1355-1358.

22. Snetselaar, K. M., and Mims, C. W. 1993. Infection of maize stigmas by Ustilago maydis: Light and electron microscopy. Phytopathology 83: 843-850.

23. Snetselaar, K. M., and Mims, C. W. 1994. Light and electron microscopy of Ustilago maydis hyphae in maize. Mycol. Res. 98:347-355.

24. Snetselaar, K. M., and Tiffany, L. H. 1990. Light and electron microscopy of sorus development in Sorosporium provinciale, a smut of big bluestem. Mycologia 82:480-492.

25. Spurr, A. R. 1969. A low-viscosity epoxy resin embedding medium for electron microscopy. J. Ultrastruct. Res. 26:31-43.

26. Stromberg, E. L., Stienstra, W. C., Kommedahl, T., Matyac, C. A., Windels, C. E., and Gealdelmann, J. L. 1984. Smut expression and resistance of corn to Sphacelotheca reiliana in Minnesota. Plant Dis. 68: 880-884.

27. Vánky, K. 1994. European Smut Fungi. Gustav Fisher Verlag, Stuttgart, Germany.

28. Wilson, J. M., and Frederiksen, R. A. 1970. Histopathology of the interaction of Sorghum bicolor and Sphacelotheca reiliana. Phytopathology 60:828-833. 